\title{
COMMENT
}

\section{SETTLEMENT OFFERS CONDITIONED UPON WAIVER OF ATTORNEYS' FEES: POLICY, LEGAL, AND ETHICAL CONSIDERATIONS}

\section{INTRODUCTION}

The primary congressional goal underlying statutes authorizing awards of attorneys' fees is to encourage the private enforcement of federal laws. ${ }^{1}$ Seeking to encourage the private enforcement of Reconstruction Era and other civil rights statutes, ${ }^{2}$ Congress enacted the Civil Rights Attorney's Fees Awards Act of 1976 (Fees Act) $^{3}$ thereby ensuring that the cost of legal counsel would not deter plaintiffs with legitimate grievances from filing suit. The Fees Act provides that courts "may allow the prevailing party . . . a reasonable attorney's fee as part of the costs"4 to be paid by the losing party. ${ }^{5}$ In practice, lower courts

1 See infra text accompanying notes 56-58. See generally text accompanying notes 46-48.

- See infra text accompanying notes 56-58. See generally text accompanying notes 46-48.

- The Fees Act states in relevant part:

In any action or proceeding to enforce a provision of sections 1981, 1982,1983, 1985, and 1986 of this title, title IX of Public Law 92-318 [20 U.S.C. 1681 et seq.], or title VI of the Civil Rights Act of 1964 [42 U.S.C. 2000d et seq.], the court, in its discretion, may allow the prevailing party, other than the United States, a reasonable attorney's fee as part of the costs.

Civil Rights Attorney's Fees Awards Act of 1976, Pub. L. No. 94-559, 90 Stat. 2641, 2641, as amended by the Equal Access to Justice Act, Pub. L. No. 96-481, § 205(c), 94 Stat. 2325, 2330 (1980) (codified as amended at 42 U.S.C. § 1988 (Supp. IV 1980)).

For a description of the statutes to which the Fees Act expressly applies, see Note, Promoting the Vindication of Civil Rights Through the Attorney's Fees Awards Act, 80 ColUM. L. REv. 346, 346 n.3 (1980) [hereinafter cited as Vindication of Civil Rights]. See generally E.R. LARSON, FEDERAL COURT AWARDS OF ATTORNEY'S FEES (1981); 1 PRAGTICING LAW INSTTTUTE, COURT AWARDED FEES IN "PUBLIC INTEREST" LITIGATION (1978); Berkovitz, A Summary of Issues Involving Attorneys' Fees in Civil Rights Cases, 13 CLEARINGHOUSE REv. 282 (1979); Derfner, One Giant Step: The Civil Rights Attorney's Fees Act of 1976, 21 ST. LouIS U.L.J. 441 (1977); Larson, The Civil Rights Attorneys Fees Awards Act of 1976, 10 CLEARINGHOUSE REV. 778 (1977); Lipson, Beyond Alyeska-Judicial Response to the Civil Rights Attorneys' Fees Act, 22 ST. LoUIs U.L.J. 243 (1978); Malson, In Response to Alyeska-The Civil Rights Attorney's Fees Awards Act of 1976, 21 ST. Louls U.L.J. 430 (1977); Note, The Civil Rights Attorney's Fees Awards Act of 1976, 52 ST. John's L. REv. 562 (1978); Comment, Attorney's Fees in Damage Actions Under the Civil Rights Attorney's Fees Awards Act of 1976, 47 U. CHI. L. REV. 332 (1980); Note, The Civil Rights Attorneys' Fees Awards Act of 1976, 34 WASH. \& LEE L. REV. 205 (1977).

42 U.S.C. § 1988 (Supp. IV 1980).

- The usual situation in the United States is that each litigant, victorious or not, pays for its own attorney. This result has come to be known as the "American Rule" because of the contrasting norm in England. Statutes such as the Fees Act are termed fee shifting statutes because they reverse the American Rule by forcing the "losing" party to pay the "prevailing" party's attorney's fees. See infra note 43. 
view fee awards as almost mandatory when plaintiffs prevail. ${ }^{6}$ Furthermore, to satisfy the "prevailing party" requirement, plaintiffs need to achieve only some of their objectives" "either through success on the merits, through settlement, or merely through causing the defendants voluntarily to undertake part of the relief sought."

Computed at market rates unrelated to the amounts awarded to plaintiffs, ${ }^{9}$ awards of statutory fees often prove very costly to defendants. ${ }^{10}$ To reduce their total liability in civil rights suits, defendants frequently condition otherwise attractive settlement offers on the waiver of attorneys' fees by plaintiffs. ${ }^{11}$ Although a conditional settlement offer places a plaintiff's counsel in a conflict between his interest in fees and his client's interest in a satisfactory settlement, the current ethical code $^{12}$ does not bar a defendant's counsel from making such an offer. ${ }^{13}$ Furthermore, a plaintiff's counsel cannot ethically reject a conditional settlement offer if his client prefers to accept it. ${ }^{14}$ A conditional settlement offer thus demands "a benefit which the plaintiff's lawyer cannot resist as a matter of ethics and which the plaintiff will not resist due to lack of interest." $" 15$

This Comment adopts the view that conditional settlement offers by defendants thwart the private enforcement of the civil rights laws. ${ }^{16}$ Because the enforcement of the civil rights laws relies heavily on suits

- See, e.g., Gates v. Collier, 616 F.2d 1268, 1275 (5th Cir. 1980) (fees should be awarded almost "as a matter of course"); E.R. LARSON, supra note 3, at 33 ("a prevailing plaintiff is entitled to fees as a matter of course unless special circumstances would render an award unjust").

'See, e.g., Northcross v. Board of Educ., 611 F.2d 624 (6th Cir. 1979), cert. denied, 447 U.S. 911 (1980). This issue is pending before the Supreme Court in Hensley v. Eckerhart, 664 F.2d 294 (8th Cir. 1981), cert. granted, 455 U.S. 988 (1982) (No. 81-1244).

- E.R. LARSON, supra note 3, at 33; see H.R. REP. No. 1558, 94th Cong., 2d Sess. 6-7 (1976); S. REP. No. 1011, 94th Cong., 2d Sess. 5 (1976), reprinted in 1976 U.S. CODE CONG. \& AD. NEWS 5908, 5912.

- See infra notes 37-39 and accompanying text for a discussion of the methods used by courts to determine statutory fees awards.

10 Statutory fees can exceed the damages awarded. See, e.g., Copeland v. Marshall, 641 F.2d 880,893 (D.C. Cir. 1980 ) (en banc) $(\$ 33,000$ recovery, $\$ 160,000$ attorney's fees); Skoda v. Fontani, 519 F. Supp. 309, 310 (N.D. Ill. 1981) (\$1 recovery, \$6,086.12 attorney's fees).

11 Request for fee waivers reportedly occur in more than half of the civil rights cases litigated. Fee Waiver Requests Unethical: Bar Opinion, 68 A.B.A. J. 23 (1982) (quoting E. Richard Larson, national staff counsel to the American Civil Liberties Union).

1s MODEL CODE OF PROFESSIONAL RESPONSIBILITY (1981).

13 See infra notes $124-27$ and accompanying text.

14 See infra text following note 122 . Lawyers are ethically bound to defer to their clients' wishes with respect to settlements. See infra note 121 and accompanying text. But see infra text accompanying notes 161-63.

${ }^{25}$ New York City Bar Ass'n Comm. on Professional and Judicial Ethics, Formal Op. 80-94 (1981), reprinted in 36 THE RECORD OF THE ASSOCIATION OF THE BAR OF THE CITY OF NEW YORK 507, 508 (1981) (hereinafter cited as REC. A.B. CITY N.Y.]; see also Levin, Practical, Ethical and Legal Consideration Involved in the Settlement of Cases in which Statutory Attorney's Fees are Authorized, 14 GLEARINGHOUSE REV. 515 (1980).

10 See infra text accompanying note 164. 
by private citizens, ${ }^{17}$ many of whom are unable to afford the cost of legal counsel, ${ }^{18}$ Congress concluded that the awarding of statutory fees is the only means available for certain citizens to finance their legal representation. ${ }^{19}$ By enacting the Fees Act, Congress sought to guarantee a viable pool of attorneys who, secure in their expectation of fees from a successful action, will undertake to represent citizens in obtaining judicial enforcement of their rights under the civil rights laws. ${ }^{80}$ The routine bargaining away of statutory fees by plaintiffs who have no financial interest in them, however, discourages lawyers from representing future clients who must rely on the Fees Act to finance their legal representation. The goals of the Fees Act cannot be achieved if attorneys decline to represent civil rights plaintiffs out of fear that they will be uncompensated even when their clients prevail. Permitting conditional settlement offers by defendants effectively removes many members of the plaintiffs' civil rights bar from the scene and materially quells the vigorous enforcement of the laws. Hence, although a conditional settlement offer may provide relief to plaintiffs in a particular case, its routine use threatens to leave future victims of civil rights violations without legal representation. Neither courts nor ethical codes should permit the undermining of these congressionally favored rights.

After a brief overview of fee awards under the Fees Act, part I of this Comment examines conditional settlement offers in light of Congress's policies in enacting the Fees Act and in light of emerging case law. Part II discusses problems arising from evaluating the ethical propriety of conditional settlement offers under the Code and analyzes an opinion issued by the Ethics Committee of 'the New York City Bar Association condemning such offers. Part III proposes a rule by which courts can shield plaintiffs' lawyers from coercive conditional settlement offers without precluding defendants from obtaining the information necessary for them to assess their liability from statutory fees.

17 See infra text accompanying notes $46-48,5 \%-60$ \& 134-37.

18. See infra text accompanying notes 49,55 \& 134-37.

10 See infra text accompanying notes $46-48$.

20 See infra text accompanying notes $46-48$ \& 56-60. By creating a method whereby attorneys undertaking representation in civil rights suits will be compensated if the suit prevails, Congress took a great step toward effective enforcement of the civil rights laws. First, more attorneys will be willing to undertake civil rights suits if they know they will be compensated if the suit prevails. Thus, there will be more persons available to enforce the civil rights laws. This is a very important factor when it is considered that the government has limited authority and resources to enforce civil rights statutes. See infra text accompanying note 46 . The increased number of attorneys willing to enforce civil rights laws also acts as a deterrent because it increases the chances of a violator being detected and sued. Second, the prospect of attorneys' fees is an effective deterrent of civil rights violations especially because merely injunctive relief often imposed for a violation does not entail direct economic costs on the defendant sufficient to deter future violations. This factor can be formidable, see supra note 10. 


\section{Conditional Settlement Offers: Congressional SILENCE AND JUdicial UNCERTAINTY}

\section{A. Background: Fee Awards}

The Fees Act authorizes an award of fees to "the prevailing party."221 Although both plaintiffs and defendants are eligible for statutory fees, a prevailing defendant is entitled to attorneys' fees only if the plaintiff's law suit was brought in bad faith or for harassment purposes, ${ }^{22}$ or was clearly frivolous, unreasonable, or groundless. ${ }^{23} \mathrm{~A}$ prevailing plaintiff, on the other hand, is entitled to statutory fees as a matter of course "unless special circumstances would render such an award unjust."24 Among proffered "special circumstances," a defendant's good faith, ${ }^{25}$ a plaintiff's demonstrated ability to pay his attorney's fees, ${ }^{26}$ and representation of a plaintiff for free by a public interest lawyer ${ }^{27}$ have all been rejected as grounds for denying statutory fees to a prevailing plaintiff. ${ }^{28}$

To be deemed a "prevailing party,"20 a plaintiff needs to achieve only some of its objectives either through success on the merits, ${ }^{30}$ through settlement, ${ }^{31}$ or merely through prompting the defendant voluntarily to undertake part of the relief sought. ${ }^{32}$ A plaintiff is entitled

1142 U.S.C. \& 1988 (Supp. IV 1980).

23 See H.R. REP. NO. 1558, supra note 8 , at 7; S. REP. NO. 1011, supra note 8 , at 5 , reprinted in 1976 U.S. CODE CONG. \& AD. NEWS 5908, 5912; E.R. LARSON, supra note 3, at 85.

23 See Hughes v. Rowe, 449 U.S. 5 (1980) (citing Garment Co. v. EEOC, 434 U.S. 412 (1978)); E.R. LARSON, supra note 3, at 85-86, 92. Courts treat a defendant, or defendant intervenor, enforcing rights protected by a statute as a plaintiff, however, for purposes of awarding fees. See, e.g., Ridell v. National Democratic Party, 624 F.2d 539 (5th Gir. 1980); E.R. LARSON, supra note 3 , at $42-44$.

21 Newman v. Piggie Park Enters., Inc., 390 U.S. 400, 402 (1968), quoted in H.R. REP. No. 1558, supra note 8, at 6; and in S. REP. No. 1011, supra note 8, at 4, reprinted in 1976 U.S. CODE CONG. \& AD. NEWS 5908, 5912.

${ }_{23}$ See, e.g., Hutton v. Finney, 437 U.S. 678 (1978); Love v. Mayor of Cheyenne, 620 F.2d 235 (10th Cir. 1980); Johnson v. Mississippi, 606 F.2d 635 (5th Cir. 1979); Mid-Hudson Legal Servs., Inc. v. G \& U, Inc., 578 F.2d 34 (2d Cir. 1978).

26 See, e.g., International Oceanic Enters., Inc. v. Menton, 614 F.2d 502 (5th Cir. 1980); International Soc'y for Krishna Consciousness, Inc. v. Collins, 609 F.2d 151 (5th Cir. 1980).

27 See, e.g., New York Gaslight Club, Inc. v. Carey, 447 U.S. 54, 71 n.9 (1980) (citing H.R. REP. No. 1558, supra note 8, at 5, 8 n.16); Dennis v. Chang, 611 F.2d 1302 (9th Cir. 1980); Northcross v. Board of Educ., 611 F.2d 624 (6th Cir. 1979), cert. denied, 447 U.S. 911 (1980); Holley v. Lavine, 605 F.2d 638 (2d Cir. 1979).

28 For other alleged "special circumstances" that have been rejected as grounds for denying statutory fees to prevailing plaintiffs, see E.R. LARSON, supra note 3, at 45-50.

20 See generally E.R. LARSON, supra note 3, at 33-97.

${ }^{20}$ Sec, e.g., Familias Unidas v. Briscoe, 619 F.2d 391 (5th Cir. 1981); Bagby v. Beal, 606 F.2d 411 (3d Cir. 1979); Naudeau v. Helgemoe, 581 F.2d 275 (1st Cir. 1978).

s1 See Maher v. Gagne, 448 U.S. 122 (1980) (quoting S. REP. No. 1011, supra note 8, at 5, reprinted in 1976 U.S. CODE CONG. \& AD. NEWS 5908, 5912).

23 See, e.g., Dayan v. Board of Regents, 620 F.2d 107 (5th Cir. 1980); Dawson v. Pastrick, 600 F.2d 70 (7th Cir. 1979); International Soc'y for Krishna Consciousness, Inc., v. Andersen, 569 F.2d 1027 (8th Cir. 1977); cf. Parham v. Southwestern Bell Tel. Co., 433 F.2d 421 (8th Cir. 
to a fees award upon prevailing on statutory grounds, ${ }^{33}$ whether in federal or state court. ${ }^{34}$ Furthermore, the eleventh amendment does not bar an award of fees against a state or its officials. ${ }^{35}$

The federal courts of appeal have adopted different methods of computing statutory fees. No circuit, however, presently adheres to a simplistic percentage of recovery method. ${ }^{36}$ The circuits generally agree as to the factors that should be considered in computing fees, ${ }^{37}$ giving particular attention to the hours of work claimed by the attorney and to his customary billing rate. ${ }^{38}$ The varying approaches to fee computation differ only as to the guidance provided to the lower courts about how the factors are to be applied. ${ }^{39}$

\section{B. Conditional Settlement Offers and the Congressional Goal of Private Enforcement of Civil Rights}

The plain language and legislative history of the Fees Act are silent with respect to conditional settlement offers; they neither expressly condone nor prohibit the practice. ${ }^{40}$ It is thus appropriate to consider

1970) (plaintiff is entitled to fees because his lawsuit acted as a "catalyst" prompting defendant to seck compliance with the requirements of Title VII), cited in H.R. REP. NO. 1558, supra note 8, at 7; and in S. REP. No. 1011, supra note 8, at 5, reprinted in 1976 U.S. CODE CONG. \& AD. NEWS 5908, 5912.

"See Maine v. Thiboutot, 448 U.S. 1 (1980).

St See id.

ss See Hutto v. Finney, 437 U.S. 678 (1978); see also Maher v. Gagne, 448 U.S. 122 (1980).

26 Cf., e.g., Furtado v. Bishop, 635 F.2d 915 (1st Cir. 1980) (reversing a trial court's award of fees limited to half the damage recovery).

s7 "Both the Johnson approach and the lodestar method utilize virtually the same factors." E.R. LARSON, supra note 3 , at 136. The twelve Johnson factors include, inter alia, the time and labor required, the novelty and difficulty of the questions involved, the skill needed to present the case, and the customary fee for similar work. See Johnson v. Georgia Highway Express, Inc, 488 F.2d 714 (5th Cir. 1974) (Title VII), cited in H. R. REP. No. 1558, supra note 8, at 8; and in S. REP. NO. 1011, supra note 8, at 6, reprinted in 1976 U.S. CODE CONG. \& AD. NEWS 5908, 5913. Whereas the Johnson approach merely lists the factors a trial court must consider in determining a fees award, the lodestar method provides "a procedure for ordering the examination of factors." Stanford Daily v. Zurcher, 64 F.R.D. 680, 682 (N.D. Gal. 1974), aff', 550 F.2d 464 (9th Gir. 1977), rev'd on other grounds, 436 U.S. 547 (1978). Under the lodestar method, courts multiply the number of compensable hours by an appropriate billing rate and then adjust this sum-the lodestar-in light of the contingent nature of success and the quality of the attorney's work. See Lindy Bros. Builders, Inc. v. American Radiator \& Standard Sanitary Corp., 487 F.2d 161 (3d Cir. 1973) (antitrust); see also Copeland v. Marshall, 641 F.2d 880 (D.C. Cir. 1980) (en banc) (Title VII); Leubsdorf, The Contingency Factor in Attorney Fee Awards, 90 YALE L.J. 473 (1981).

see supra note 37.

30 See E.R. LARSON, supra note 3, at 136; cf. Copper Liquor, Inc. v. Adolph Coors Co., 624 F.2d 575 (5th Cir. 1980) (antitrust) (holding that the Johnson factors are best applied in a manner almost identical to the lodestar method).

40 Examination of the Fees Act's legislative history is otherwise complicated by the unusual manner in which it was enacted. For a discussion of the enactment of the House and Senate bills, see Malson, supra note 3, at 432-36; Comment, Civil Rights Attorneys' Fees in Cases Resolved on State Pendent and Federal Statutory Grounds, 130 U. PA. L. REV. 488, 495 n.34 (1981). Courts have nevertheless relied on the Fees Act's legislative history and case law to interpret other fee 
whether permitting a defendant to insist on a waiver of statutory fees as a condition of settling a civil rights suit is consistent with the Act's purpose. This involves determining the "general aim or policy which pervades a statute."41

Congress's enactment of the Fees Act was partly a response to the Supreme Court's decision in Alyeska Pipeline Service Co. v. Wilderness Society. ${ }^{\mathbf{2}}$ In Alyeska, the Court held that, absent specific congressional authorization, the federal courts lacked the equitable powers to award attorneys' fees for cases brought in the public interest. ${ }^{43}$ Many perceived Alyeska as "erect[ing] a formidable financial barrier against those seeking access to Federal courts."44 Congress thus sought to ensure effective access to the judicial system for those seeking redress under the civil rights laws. ${ }^{45}$

Effective access to the courts by victims of civil rights violations is made more important because of the government's limited authority and resources to enforce civil rights statutes. ${ }^{46}$ The enforcement of the

shifting statutes. See, e.g., New York Gaslight Club, Inc. v. Carey, 447 U.S. 54, 70-71 n.9 (1980) (Title VII); Gram v. Bank of La., 691 F.2d 728, $729-30$ (5th Cir. 1982) (Truth in Lending Act); Donnell y. United States, 682 F.2d 240, 244-55 (D.C. Cir. 1982) (Voting Rights Act); cf. E.R. LARSON, supra note 3, at 6 (the Fees Act's legislative history "also is useful in interpreting similar fee-shifting statutes") (footnote omitted).

42 Cox, Judge Learned Hand and the Interpretation of Statutes, 60 HARV. L. REV. 370, 370 (1947); see also Llewellyn, Remarks on the Theory of Appellate Decision and the Rules or Canons About How Statutes Are To Be Construed, 3 VAND. L. REV. 395, 400-01 (1950):

If a statute is to make sense, it must be read in the light of some assumed purpose....

But . . . its language is [often] called upon to deal with circumstances utterly uncontemplated at the time of its passage. Here the quest is not properly for the sense originally intended by the statute, for the sense sought originally to be put into it, but rather for the sense which can be quarried out of it in the light of the new situation. Broad purposes can indeed reach far beyond details known or knowable at the time of the drafting. . . . [T] he sound quest [for a statute's policy] does not run primarily in terms of historical intent. It runs in terms of what the words can be made to bear, in making sense in the light of the unforeseen.

421 U.S. 240 (1975).

4: In Alyeska, a coalition of environmental groups prevailed in its suit against those responsible for constructing the trans-Alaska oil pipeline. The plaintiffs sought fees under the "private attorney general" exception to the "American Rule"- that litigants pay their own attorneys' fees, see id. at 240-62-which had been employed by several courts of appeals. The Court, however, held that "it would be inappropriate for the Judiciary, without legislative guidance, to reallocate the burdens of litigation." Id. at 247. Rather, the Court noted "that the circumstances under which attorneys' fees are to be awarded and the range of discretion of the courts in making those awards are matters for Congress to determine." Id. at 262.

For a brief discussion and comparison of the American and European rules concerning attorneys fees, see Vindication of Civil Rights, supra note 3, at 347-50; Comment, supra note 40, at 488-89 n.1.

4 122 CONG. REC. 31,471 (1976) (remarks of Sen. Mathias).

4b See H.R. REP. No. 1558, supra note 8, at 1 (the Fees Act "is designed to give [victims of civil rights violations] effective access to the judicial process . . . .").

10 See id. 
civil rights laws thus depends heavily upon "private attorneys general": suits brought by private citizens in which "an attorney is a practical necessity." 47 Prior to Alyeska, suits by private attorneys general had resulted in the "vigorous enforcement of modern civil rights legislation, while at the same time limiting the growth of the [government's] enforcement bureaucracy."48

Yet, Congress noted that "a vast majority of the victims of civil rights violations cannot afford legal counsel." 49 Of course, in a case involving a damage award, the attorney may arrange a contingency fee agreement with the plaintiff. Under such an arrangement, the attorney would receive a certain percentage of the court awarded damages. ${ }^{80}$ Some civil rights statutes, however, preclude damage awards, allowing only injunctive relief. ${ }^{51}$ Moreover, Congress noted that even in a situation in which a damage award is the appropriate remedy, such an award may be "preclude[d] or severely limit[ed]" because of immunity doctrines if the civil rights violator is a state or local government entity. ${ }^{62}$ The costs of civil rights suits thus "frequently outrun the economic benefits ultimately obtained by successful litigants." relief and immunity doctrines necessarily restrict the civil rights attorney's ability to arrange a contingency fee arrangement with the client. st $^{\text {s. }}$ Inability to arrange for fee payment forces the victims of civil rights violations to abandon their claims "because they cannot shoulder the

47 Miller v. Amusement Enters., Inc., 426 F.2d 534, 539 (5th Cir. 1970).

a S. REP. No. 1011, supra note 8, at 4, reprinted in 1976 U.S. CODE CONG. \& AD. NEWS $5908,5911$.

40 H.R. REP. No. 1558, supra note 8, at 1 ; see also S. REP. No. 1011, supra note 8, at 2 , reprinted in 1976 U.S. CODE CONG. \& AD. NEWS 5908, 5910.

so See generally F.B. MACKINNON, CONTINGENT FEES FOR LEGAL SERVICES (1964).

BI For example, the Senate Report notes that a plaintiff bringing an action under title II of the Civil Rights Act of 1964 may obtain injunctive relief only. S. REP. NO. 1011, supra note 8, at 3, reprinted in 1976 U.S. CODE CONG. \& AD. NEWS 5908, 5910. In discussing the House version of the Fees Act the House Report states that "in a large number of cases brought under the provisions covered by H.R. 15460, only injunctive relief is sought, and prevailing plaintiffs should ordinarily recover their counsel fees." H.R. REP. N.0. 1558, supra note 8, at 9.

B2 H.R. REP. No. 1558 , supra note 8 , at 9.

ss 122 CONG. REC. 31,472 (1976) (remarks of Sen. Kennedy); see also id. at 33,314 (remarks of Sen. Kennedy) ("often no large promise of monetary recovery lies at the end of the tunnel"). Senator Kennedy was a principal sponsor of the Fees Act legislation. See id. at 31,471 (Kennedy substitute for Tunney bill); cf. id. at 31,850 (amendment by Sen. Allen to entitle the bill the "Tunney-Kennedy Civil Rights Attorneys Relief Act of 1976").

st Cf. id. at 33,314 (remarks of Sen. Kennedy): "civil rights cases-unlike tort or antitrust cases-do not provide the prevailing plaintiff with a large recovery from which he can pay his lawyer." Moreover, the limited resources of public interest organizations do not allow them to litigate all the worthy suits that come to their attention. See generally COUNCIL FOR PUBLIC IN. TEREST LAW, BALANCING THE SCALES OF JUSTICE: FinaNCING PUBLIC INTEREST LAW IN AMERICA (1976); Nussbaum, Attorney's Fees in Public Interest Litigation, 48 N.Y.U. L. REV. 301 (1973); Note, Allowance of Attorney Fees in Civil Rights Actions, 7 ColuM. J.L. \& SOC. PROBS. 381 (1971). 
full costs of vindicating their rights."'55

By enacting the Fees Act, Congress sought to remove the most significant barrier to legal representation against those victims of civil rights violations seeking access to federal courts: payment of attorney fees. "The entire purpose of the [Fees Act] was to ensure that the representation of important national concerns would not depend upon the charitable instincts of a few generous attorneys." on the Fees Act, for example, states:

The Committee also received evidence that private lawyers were refusing to take certain types of civil rights cases because the civil rights bar, already short of resources, could not afford to do so. Because of the compelling need demonstrated by the testimony, the Committee decided to report [the Fees Act bill]. ${ }^{\text {sz }}$

Statements made during the Senate debate on the Fees Act further support the position that Congress viewed providing private citizens with the financial means with which to secure legal counsel in civil rights suits as the cornerstone of the Fees Act. ${ }^{68}$ Congress viewed private attorneys' expectation of fees when successful in their representation of clients-whether by settlement or otherwise-as the essential element of the Fees Act's private enforcement scheme. Not to award counsel fees would be "tantamount to repealing" the civil rights statutes themselves by frustrating their basic purpose. ${ }^{69}$ The national importance of the rights being litigated compels the awarding of fees. ${ }^{60}$

Congress thus found that entitlement to statutory attorneys' fees

ss 122 CONG. REC. 31,472 (1976) (remarks of Sen. Kennedy).

be Northcross v. Board of Educ., 611 F.2d 624, 638 (6th Cir. 1979), cert. denied, 447 U.S. 911 (1980).

${ }^{87}$ H.R. REP. No. 1558 , supra note 8 , at 3; cf. S. REP. No. 1011, supra note 8 , at 6 , reprinted in 1976 U.S. CODE CONG. \& AD. NEWS 5908, 5913 ("If the cost of private enforcement actions becomes too great, there will be no private enforcement. If our civil rights laws are not to become mere hollow pronouncements which the average citizen cannot enforce, we must maintain the traditionally effective remedy of fee shifting in these cases.").

s See 122 CONG. REC. 31,471 (1976) (remarks of Sen. Mathias) ("The goal of S. 2278 is clear and compelling - to insure that the high cost of litigation does not bar the Federal courts to citizens who seek to enforce their rights under our civil rights laws."); id. at 33, 313 (remarks of Sen. Tunney) ("Private citizens must be given not only the rights to go to court, but also the legal resources. . . . Attorneys' fees have proved one extremely effective way to provide these equal legal resources .....").

89 S. REP. NO. 1011, supra note 8, at 3, reprinted in 1976 U.S. CODE CONG. \& AD. NEWS 5908,5910 (quoting Hall v. Cole, 412 U.S. 1 (1973)).

* See Northcross v. Board of Educ., 611 F.2d 624, 633 (6th Cir. 1979), cert. denied, 447 U.S. 911 (1980); cf. Alyeska Pipeline Serv. Co. v. Wilderness Society, 421 U.S. 240, 264 (1975) ("II] any statutory policy is deemed so important that its enforcement must be encouraged by awards of attorneys' fees, how could a court deny attorneys' fees to private litigants in actions under 42 U.S.C. \$ 1983 seeking to vindicate constitutional rights?" (emphasis in original)). 
was an essential prerequisite to enforcement of our civil rights laws. Hence, the clear public policy is to discourage practices that interfere with the awarding of attorneys' fees to prevailing plaintiffs. Yet, conditional settlements provide relief to plaintiffs in individual cases only by securing a waiver of any entitlement to statutory fees. Furthermore, although plaintiffs' counsel in some situations may offer voluntarily to waive any claim to statutory fees, most conditional settlement offers are initiated by defendants. ${ }^{61}$ Given plaintiffs' counsels' ethical obligation to seek the best relief for their clients, ${ }^{62}$ conditional settlement offers by defendants effectively bar ethical lawyers from ever recovering statutory fees in civil rights cases. ${ }^{\text {es }}$ Finally, conditional settlement offers are most likely in those situations where Congress intended statutory fees to be most beneficial to civil rights plaintiffs: cases where small monetary damages or only nonpecuniary relief is available. ${ }^{64}$

\section{Conditional Settlement Offers and the Courts}

No federal court has expressly prohibited conditional settlement offers. ${ }^{65}$ In James v. Home Construction Co. ${ }^{68}$ the Court of Appeals for the Eleventh Circuit observed in dictum that Congress could not have intended for a plaintiff to bargain away his attorney's claim to a statutory fees award. ${ }^{67}$ The court noted that the award of attorneys' fees is "a critical and integral part" of Congress's scheme of effective enforcement of federal laws by private citizens without government intervention..$^{68}$ "In order to effectuate this scheme, attorneys who bring [suits under private attorney general statutes] should be secure in their

-1 See supra note 11 and accompanying text.

6. See infra text accompanying notes 104-07.

* But see infra text accompanying notes 161-63.

- See supra notes 52-53 and accompanying text.

as Simultaneous negotiations of the merits of the suit and attorneys' fees, however, have been prohibited thereby barring conditional settlement offers. See infra notes 78-82 and accompanying text.

689 F.2d 1357 (11th Cir. 1982).

67 See id. at 1359. In holding that the Truth in Lending Act (TILA), Pub. L. No 90-321, 82 Stat. 146 (1968), amended by Pub. L. No. 91-508, 84 Stat. 1126 (1970) (codified in scattered sections of 15 U.S.C.), "creates a right of action for attorneys to seek fee awards after settlement of the plaintiff's claim," 689 F.2d at 1359, the court stated that "it is the attorney who is entitled to fee awards in a TILA case, not the client." Id. at 1358. TILA's provision for attorneys' fees states in relevant part:

[A]ny creditor who fails to comply with any requirement imposed under this part ... with respect to any person is liable to such person in an amount equal to the sum of - (3) in the case of any successful action to enforce the foregoing liability ... the costs of the action, together with a reasonable attorney's fee as determined by the court.

15 U.S.C. \& 1640(a)(3) (1976).

4689 F.2d at 1359. 
expectation of fees from a successful action . . .." Conditional settlement offers, however, "thwart both the statute's private enforcement scheme and its remedial objectives."'70

The only case to date where a plaintiff's counsel has resisted a defendant's insistence on waiver of fees by filing a motion with the court during settlement negotiations is Chattanooga Branch of the NAACP v. City of Chattanooga. ${ }^{71}$ In Chattanooga NAACP, plaintiffs filed suit challenging certain rezoning plans as racially discriminatory. ${ }^{72}$ During settlement negotiations, plaintiffs' counsel filed a motion petitioning the court to prohibit defendants from insisting that counsel waive statutory fees as part of the settlement on the merits. The court declined, instead directing the parties to resume negotiations. The court further instructed plaintiffs' counsel to act in the clients' interest and made clear to all counsel that disagreement over fees should not preempt settlement. Plaintiffs' counsel waived fees and all parties entered into a consent decree. Plaintiffs' counsel subsequently sought to set aside only that provision of the consent decree waiving statutory fees. ${ }^{23}$ Defendants opposed the motion for fees and alternatively moved to set aside the entire consent decree if the fee waiver was declared unenforceable. $^{74}$ The court denied plaintiffs' motion for fees stating that the consent decree should stand in its entirety. ${ }^{75}$

ฯ Id.

70 Id.

71 No. 79-2111 (D. Tenn. Dec. 2, 1981), appeal dismissed, Nos. 82-5016/5013 (6th Cir. Apr. 29, 1982). The facts set forth were gleaned from Brief of Plaintiffs-Appellants at 1-11, Chattanooga Branch of NAACP v. City of Chattanooga, Nos. 82-5016/5013 (6th Cir. dismissed Apr. 29, 1982).

72 This multiparty action was brought by the local NAACP branch and three lower income black women ("minority plaintiffs"), housing developer plaintiffs, and the National Committee Against Discrimination in Housing, Inc., (NCDH), against municipal and federal defendants. The prayer for relief included requests for damages for the developers, declaratory and injunctive relief for all plaintifis, and attorneys' fees.

78 The dispute over statutory fees after entry of the consent decree was solely between the parties obtaining only nonpecuniary relief (i.e., minority plaintiffs and NCDH) and their counsel, and the defendants.

76 See Brief of the Montgomery County Fair Housing Center as Amicus Curiae at 4, Chattanooga Branch of NAACP v. City of Chattanooga, Nos. 82-5016/5013 (6th Cir. dismissed Apr. 29, 1982).

75 Minority plaintiffs, NCDH, and their counsel appealed the trial court's denial of statutory fees. Defendants filed a cross-appeal seeking to set aside the entire consent decree in the event that the provision waiving statutory fees were set aside and in support of the district court's denial of fees. Both appeals were voluntarily dismissed.

The same factor that effectively coerced the waiver of fees-the risk of losing federal funds as relief-may have also coerced the plaintiffs to withdraw their appeal. The most adequate remedy in discriminatory land use, fair housing cases is housing units rather than mere damages. See Brief of Plaintiffs-Appellants at $22 \mathrm{nn} .13-14$, Chattanooga NAACP. The federal defendant agreed in the consent decree to preserve funds from its budget for fiscal year 1981 to guarantee rent subsidies for the developers' housing project. See id. at 21 . Had the entire consent decree been set aside, these funds could have been recaptured by the defendant and "lost forever to the developers' project in Chattanooga." See id. at 22. The risk of having the entire consent decree set aside may have 
In contrast to the Tennessee District Court's ruling in Chattanooga NAACP, the Court of Appeals for the Third Circuit has held that the policies underlying the Fees Act override the interest in enforcement of the terms of a private agreement barring a plaintiff's attorneys from requesting or accepting statutory fees. ${ }^{78}$ In Shadis $v$. Beal, ${ }^{77}$ the court affirmed a lower court's refusal to enforce a provision in a funding contract between plaintiff's lawyers' legal services program and the defendant Commonwealth of Pennsylvania. The contractual provision purported to bar awards of attorneys' fees to plaintiffs in litigation against the state. The lower court recognized precisely what renders such agreements contrary to public policy: "If such agreements were enforceable, the entity. or person could programmatically require such agreements from any number of lawyers with whom it deals, thus diminishing the scope and vitality of the inducement Congress wished to create." 38

Conditional settlement offers are possible only during simultaneous negotiations of attorneys' fees with the settlement of the substantive dispute between the parties. In Prandini v. National Tea Co., ${ }^{78}$ the Court of Appeals for the Third Circuit expressly directed its trial courts to insist upon settlement of the merits of the case separately from the award of statutory fees. ${ }^{80}$ Only after court approval of a settlement on the merits should discussion and negotiation of "appropriate compensation for the attorneys begin."81 Two other courts of appeal, the Eighth and Ninth Circuits, also have expressed disfavor for simultaneous negotiations. ${ }^{82}$

thus coerced plaintiffs to withdraw their appeal from the denial of fees.

76 See Shadis v. Beal, 685 F.2d 824 (3d Cir.), cert. denied, 103 S. Ct. 300 (1982).

II I.

76 Shadis v. Beal, 520 F. Supp. 858, 864 n.8 (E.D. Pa. 1981), affd, 685 F.2d 824 (3d Cir.), cert. denied, 103 S. Ct. 300 (1982).

757 F.2d 1015 (3d Cir. 1977). Prandini was a class action employment discrimination suit seeking damages and injunctive relief.

- See id. at 1021. For a critical view of Prandini, see Levin, supra note 15, at 516-17; Note, Attorney's Fees-Conflicts Created by the Simultaneous Negotiation and Settlement of Damages and Statutorily Authorized Attorneys' Fees in a Title VII Class Action, 51 TEMPLE L.Q. 799 (1978).

-1 557 F.2d at 1021. In Prandini, the court's concern was the apparent conflict of interest posed by "sweetheart contracts," i.e., a defendant's proffer of generous attorneys' fees to plaintiff's counsel in tacit exchange for a small recovery or other remedial concessions. See id. at 1021 \& n.7. Yet, whether proposed settlements make extremely generous or totally inadequate provisions for plaintiffs' counsels' remuneration, they raise conflict of interest problems which can arise only in simultaneous negotiations.

a See Obin v. District No. 9 of the Int'l Ass'n of Machinists, 651 F.2d 574, 582 \& n.10 (8th Cir. 1981) (simultaneous negotiations place counsel "in the position of negotiating a fee ultimately destined for his pocket at the same time that all thoughts ought to be singlemindedly focused on the client's interests," id. at 582; "it is preferable to avoid any appearance of impropriety even if an agreement on fees may be "easily accomplished," "id. at 582 n.10); Mendoza v. United States, 623 F.2d 1338, 1353 (9th Cir. 1980) ("we strongly discourage the simultaneous negotiation of 
If followed by trial courts, the Prandini bifurcated approach to settlement negotiations theoretically removes any opportunity for defendants to make conditional settlement offers. Yet, that approach also presents problems. ${ }^{83}$ First, enforcement of the Prandini rule is difficult, ${ }^{84}$ even in class action suits where the court must approve all settlements. ${ }^{80}$ The court, for example, ordinarily cannot know whether the parties have had discussions on fee matters. The rule's "net result might be to increase informal agreements among counsel or to encourage withholding agreements on fees from the judge until after the settlement is approved." ${ }^{\prime 86}$ Nevertheless, the rule would assist litigants petitioning the court to prohibit opposing counsel from insisting on waiver of fees as a condition of settlement. ${ }^{87}$

Second, the Prandini rule may actually inhibit favorable settlement offers. ${ }^{88}$ "By preventing [pre-judgment] agreements on fees, [Prandini] makes it difficult for the defendant to ascertain precisely what its liability will be under a proposed settlement, eliminating the very certainty that makes settlement attractive to the defendant." ${ }^{39}$ Unless a defendant can determine the likely size of a plaintiff's counsel's fee request, a litigant strictly adhering to Prandini may risk preempting settlement. ${ }^{90}$

attorneys' fees and substantive issues in class action settlement negotiations"); see also Monel v. Department of Social Serv, 24 Fair Empl. Prac. Cas. (BNA) 701, 706 (S.D.N.Y. 1980); Muñoz v. Arizona State Univ., 80 F.R.D. 670,-671-72 (D. Ariz. 1978); Lyon v. Arizona, 80 F.R.D. 665, 669 (D. Ariz. 1978); Regalado v. Johnson, 79 F.R.D. 447, 451 (E.D. Ill. 1978). But see White v. New Hampshire Dep"t of Employment Sec., 629 F.2d 697, 705 (1st Cir. 1980) ("[n]or . . . do we see anything wrong with requiring the parties to face up to the issue of fees in their settlement negotiations"), rev'd on other grounds, 455 U.S. 445 (1982).

Responses by judges and lawyers to a questionnaire prepared by the Federal Judicial Center reveals "a tendency on the part of the judges to agree with the [Prandini] decision and an even stronger agreement by attorneys, with about half the judges [51.9\%] and over half the attorneys [65.6\%] indicating agreement." A. MILLER, ATTORNEYS' FEES IN CLASS ACTIONS 224 (1980). Attorneys still agreed with Prandini when their responses were broken down according to whether the attorney represented mainly plaintiffs or defendants, $65.0 \%$ and $59.4 \%$ respectively. Id.

ss See A. MILLER, supra note 82, at 222.

os Id.

as See FED. R. GIV. P. 23(c).

86 A. MILleR, supra note 82, at 222. Enforcement of the Prandini effort to remove ethical conflicts from settlement negotiations is a problem only when defendant proffers extremely generous fees. When defendant makes totally inadequate provision for counsel's fees, plaintiff's counsel is likely to bring defendant's simultaneous discussion of merits and fees to the court's attention. See supra text following note 72 .

${ }^{87}$ For example, had the parties in Chattanooga NAACP, see supra notes 71-75 and accompanying text, been litigating in a jurisdiction that followed Prandini, theoretically either defendants would have refrained from making conditional settlement offers or the trial judge, when requested by plaintiffs, would have been obliged to instruct defendants to cease insisting on a waiver of fees as a condition of settlement. But compare infra note 90 for a discussion of Prandinis actual effect on settlement negotiations in the Third Circuit.

83 A. MILlER, supra note 82, at 222; cf. Rhode, Class Conficts in Class Actions, 34 STAN. L. REV. 1183, 1207 (1982) (refusal to discuss fees until agreement on all other issues is final "is not necessarily in anyone's interest if it inhibits favorable settlement offers").

* A. Miller, supra note 82, at 222.

- [A] defendant with good prospects for escaping any significant adverse judgment 
In a recent case, White v. New Hampshire Department of Employment Security, ${ }^{91}$ petitioner and amici urged the United States Supreme Court to adopt a rule deferring any fee negotiations until after entry of a judgment on the merits. ${ }^{82}$ The Court, although noting that it was "sensitive" to the conflict of interests problem posed by simultaneous negotiation of the merits and attorneys' fees, ${ }^{93}$ declined to decide the issue at bar $^{94}$ on the grounds urged by petitioner and amici, stating that:

\section{In considering whether to enter a negotiated settlement, a defendant may have good reason to demand to know his total}

may be willing to settle only if he knows that his total liability, including fees, will be less than the costs of defending the case. If the potential attorney's award is substantial and uncertain, the defendant may prefer to go to trial.

Rhode, supra note 88, at 1207 n.95.

Professor Miller observed that the potential disincentive to settle caused by strict adherence to Prandini "can be alleviated somewhat by allowing plaintiff's attorney to provide information as to the likely size of the request, perhaps through the judge, so defendants could accurately estimate their liability." A. MilleR, supra note 82 , at 223.

To ascertain better Prandini's impact on settlement negotiations, the University of Pennsylvania Law Review conducted telephone interviews with several district court judges in the Third Circuit. (Interview notes are on file with the University of Pennsylvania Law Review.) All the judges interviewed agreed that defendants want to know their total liability from both damages and fees. The judges believe that if a defendant does not know the full extent of its liability, it is not likely to settle. The judges have thus tried to accommodate defendants' concern by tolerating and even encouraging the litigants to discuss the information necessary for a defendant to calculate the "lodestar" figure, i.e., plaintiff's counsel's compensable hours and billing rate. See supra note 37. One judge even suggested that a court could require plaintiff's counsel to provide his cumulative timesheet to the defendant. Having calculated the lodestar figure, defendant can estimate the likely range of the fees award.

Most judges believed that the litigants' full disclosure to the court of their ongoing simultaneous discussions of the merits and fees satisfied the spirit of Prandini. Full disclosure permits the court to ferret out any existing conflict of interest problems and avoids the appearance of impropriety without inhibiting favorable settlement offers. A plaintiff's lawyer may even voluntarily reduce the number of compensable hours claimed as an incentive for defendant to settle. Curiously, none of the judges interviewed had ever been requested to enforce Prandini by instructing a defendant not to discuss fees simultaneously with the merits of the case.

Finally, some of the judges interviewed suggested that White v. New Hampshire Dep't of Employment Sec., 455 U.S. 445 (1982), see infra notes $91-95$ and accompanying text, may have modified or overruled Prandini.

1455 U.S. 445 (1982).

"See id. at 453-54 n.15. In its brief, for example, the United States concluded that "detailed -fee discussions should ordinarily be conducted after agreement on the merits has been reached" because the attorney in a civil rights action "may have an interest adverse to his client if the question of the size of his fees [award] becomes part of the settlement negotiation." Brief for the United States as Amicus Curiae at 11-12 (note and citations omitted) White.

"2 Lump sum settlement offers, where a defendant "remain[s] indifferent as to [the settlement's] distribution as 'damages' or 'attorney's fees," " was the conflict of interests problem to which the Court was sensitive. See 455 U.S. at 454 n.15. The ethical conflict arises because "[i]n pursuing negotiations . . . the lawyer must decide what allocation to seek as between lawyer and client." Id.

- The specific issue before the court in White was whether a postjudgment motion for statutory fees must be filed within the 10-day timelines standard of Rule 59(e) of the Federal Rules of Civil Procedure. See id. at 446-47. 
liability from both damages and fees. Although such situations may raise difficult ethical issues for a plaintiff's attorney, we are reluctant to hold that no resolution is ever available to ethical counsel. ${ }^{95}$

From the cases discussed, it is evident that the courts are still struggling to find a solution to the dilemma facing a plaintiff's attorney when confronted with a conditional settlement offer. Resort to judicial decisions is thus largely unhelpful in such a situation. As will be seen in the next section, the attorney ethical standards set forth in the Model Code of Professional Responsibility ${ }^{96}$ are also deficient in solving the problem.

\section{Ethical Rules and Conditional Setrlement Offers}

\section{A. The American Bar Association's View of Professional Responsibility}

\section{Generally}

The American Bar Association's Model Code of Professional Responsibility ("Code") the legal profession governs itself. ${ }^{29}$ A fundamental premise underlies the Code's standards: lawyers best serve the public interest when they faithfully, ${ }^{100}$ competently, ${ }^{101}$ and lawfully ${ }^{102}$ represent the private inter-

98 Id. at 454 n.15.

9 MODEL CODE OF PROFESSIONAL RESPONSIBILITY (1981).

97 The Code replaced the American Bar Association's Canons of Professional Ethics in 1969. The Canons, adopted in 1908, were the ABA's first codification of ethical rules.

's 'The Code comprises canons, ethical considerations (EC's), and disciplinary rules (DR's). "Strictly speaking, each canon is only the headline to each part of the Code, but the word is more commonly used to stand for the headline and the aggregation of ethical considerations and disciplinary rules that follow." Developments in the Law-Conficts of Interest in the Legal Profession, 94 HARV. L. REV. 1244, 1248 n.8 (1981) [hereinafter cited as Developments-Conflicts]. "The Ethical Considerations are aspirational in character and represent the objectives toward which every member of the profession should strive." MODEL CODE OF PROFESSIONAL RESPONSIBILITY, Preamble and Preliminary Statement (1981). "The Disciplinary Rules state the minimum level of conduct below which no lawyer can fall without being subject to disciplinary action." Id. The first number after the EC's or DR's indicates which canon the ethical consideration or disciplinary rule elaborates.

0 Every state except California has adopted the Code without substantial modification. Rhode, Why the ABA Bothers: A Functional Perspective on Professional Codes, 59 TEX. L. Rev. 689, 690 n.9 (1981). Moreover, courts in every state except Maine and Mississippi have adopted the Code as a court rule thereby giving it the force of law. Developments-Conflicts, supra note 98, at 1249. Local courts and bar ethics committees formally enforce the Code through disciplinary proceedings. There has been, however, "little empirical investigation regarding compliance with professional standards . . . ." Rhode, supra, at 708.

100 See generally MODEL CODE OF PROFESSIONAL RESPONSIBILITY Canon 5 (1981) ("A Lawyer Should Exercise Independent Professional Judgment on Behalf of a Client").

101 See generally id. Canon 7 ("A Lawyer Should Represent a Client Zealously Within the 
ests of their clients. ${ }^{103}$ Hence, an attorney's professional duty under the Code is almost exclusively to his clients. ${ }^{104}$ Neither the attorney's own interests ${ }^{108}$ nor those of third parties ${ }^{108}$ should be permitted to compromise an attorney's loyalty to his clients. ${ }^{107}$

A lawyer may nevertheless propose an action that might be inconsistent with the client's best interests if the lawyer deems the expected outcome to be morally just. ${ }^{108}$ The lawyer must, however, defer to the client's wishes on matters affecting the merits of a legal action. ${ }^{109}$ Hence, the Code states that "the decision whether to forego legally available objectives or methods because of nonlegal factors is ultimately for the client and not for [the lawyer]."110 The lawyer's inclusion of societal factors in advice to a client thus arises from the lawyer's responsibility to assist the client in reaching an appropriate decision ${ }^{111}$ rather than from any duty generally to society. ${ }^{\mathbf{1 1 2}}$

Bounds of the Law").

102 See generally id.

${ }^{102}$ Krash, Professional Responsibility to Clients and the Public Interest: Is There a Confict?, 55 CHI. B. REC. 31, 31 (Special Centennial Issue 1974); see also F.R. MARKS, K. LESWING \& B.A. FORTINSKY, THE LAWYER, THE PUBLIC, AND PROFEsSIONAL RESPONSIBILITY, at 9-10 (1972) (footnotes omitted) [hereinafter cited as MARKS \& LESWING]:

[The lawyer] is interested solely in seeing to it that the interest of the party he represents is as ably advanced as is humanly and professionally possible . . . In short, the traditional lawyer has seen himself as serving the public interest by simply doing his daily job of representing only one side of a controversy. In fact, he reasons that if he does anything but serve the singular interests of his clients he is disserving the public interest.

But cf. L. BRANDEIS, Business-A PROFESSION 318, 323 (1914), quoted in MARKS \& LESWING, supra, at 29 ("[Leaders of the bar] have erroneously assumed that the rule of ethics to be applied to a lawyer's advocacy is the same where he acts for private interests against the public as it is in litigation between private individuals.").

${ }_{106}$ See infra notes 113-19 and accompanying text for exceptions to this general rule.

10. See MODEL CODE OF PROFESSIONAL RESPONSIBILITY EC 5-2 to 5-13 (1981).

200 See id. EC 5-14 to 5-24.

102 Id. EC 5-1. See generally Developments-Conficts, supra note 101.

100 "In assisting his client to reach a proper decision, it is often desirable for a lawyer to point out those factors which may lead to a decision that is morally just as well as legally permissible." MODEL CODE OF PROFESSIONAL RESPONSIBILITY EC 7-8 (1981) (footnote omitted). See also Developments-Conficts, supra note 101, at 1459 (An attorney may "advise his client to take account of broader interests and to refuse any settlement that perpetuates a social evil.").

106 "[T] he authority to make decisions [affecting the merits of the cause] is exclusively that of the client and ... such decisions are binding on his lawyer." MODEL CODE OF PROFESSIONAL RESPONSIBILITY EG 7-7 (1981).

110 Id. EC 7-8.

11 See supra note 108.

112 See Cox, The Lawyer's Independent Calling, 67 Ky. L.J. 5, 13, 15 (1978-1979):

The lawyer must constantly look to those interests of his client which a free society allows the client to pursue, but he must also look to the needs of the larger common enterprises in which the client is engaged-ultimately to the needs of the whole human enterprise of which the client is a part. Often the two clash, either in truth or because the client's interest, as perceived by the client, clashes with the lawyer's but not the client's view of the public interest.

Plainly, it is for the client to choose after receiving the lawyer's advice. That 
Under the Code, however, a lawyer's zealous representation of his client must remain within the confines of the law. ${ }^{113}$ A lawyer may thus place refusal to aid or participate in conduct that he believes to be unlawful above the client's interests. ${ }^{114}$ Furthermore, an attorney's duty to the court overrides his loyalty to the client. ${ }^{115}$ An attorney, for example, must disclose to the court frauds perpetuated by a client upon the tribunal ${ }^{116}$ and controlling legal authority directly adverse to the client's position. ${ }^{117}$ Moreover, the Code prohibits an attorney from acquiring a financial interest in the outcome of a client's litigation ${ }^{118}$ because, if the attorney's and client's interests coincide, the attorney's duties as an officer of the court may be compromised. ${ }^{118}$

advice will be better service to the client's interest if the lawyer preserves the independence necessary to look both to what the client thinks he wants and to the larger interests of others whom the client's action will affect, including the general public. ...

....

.. . A client's true interests are seldom wholly aligned with the interests of those with whom he deals, and they may not conform at all closely with what you or I would take to be the general interest.

113 See supra note 102.

114 MODEL CODE OF PROFESSIONAL RESPONSIBILITY DR 7-101(B)(2) (1981): "In his representation of a client, a lawyer may . . . [r]efuse to aid or participate in conduct that he believes to be unlawful, even though there is some support for an argument that the conduct is legal."

116 See id. EC 7-19 to 7-33; cf. Curtis, The Ethics of Advocacy, 4 STAN. L. REv. 3, 7 (1951)

("A lawyer's duty to his client cannot rise higher than its source, which is the court.").

118 A lawyer who receives information clearly establishing that:

His client has, in the course of the representation, perpetrated a fraud upon a person or tribunal shall promptly call upon his client to rectify the same, and if his client refuses or is unable to do so, he shall reveal the fraud to the affected person or tribunal, except when the information is protected as a privileged communication.

MOdel CoDe of PRofessional ResponsibilitY DR 7-102(B)(1) (1981) (footnote omitted).

117 "In representing a matter to a tribunal, a lawyer shall disclose . . . [l]egal authority in the controlling jurisdiction known to him to be directly adverse to the position of his client and which is not disclosed by opposing counsel." Id. DR 7-106(B)(1) (footnotes omitted).

118 A lawyer shall not acquire a propietary interest in the cause of action or subject matter of litigation he is conducting for a client, except that he may:

(1) Acquire a lien granted by law to secure his fee or expenses.

(2) Contract with a client for a reasonable contingent fee in a civil case.

Id. DR 5-103(A) (footnotes omitted).

110 Developments-Conflicts, supra note 98 , at 1288. As one of two exceptions to this proscription, the Code allows a lawyer to charge a fee contingent on the outcome of civil litigation. See supra note 118 . The Code permits this arrangement because it "may be the only practical way for a client to finance adequate representation." Developments-Conflicts, supra note 98, at 1288. Moreover, the Code protects this financial arrangement by not providing defendant's counsel with any basis upon which to coerce plaintiff's counsel to waive his right to a contingent fee.

Statutory attorneys' fees may also be the only practical way for certain clients to finance their legal representation. See supra notes 54-55 and accompanying text. If the Code were to treat contingency fee arrangements and statutory fees alike, it would also not provide defendant's counsel with a basis upon which to coerce plaintiff's counsel to waive their claim to statutory fees. But cf. infra text following note 122 . 


\section{Settlements}

Most civil suits are settled out of court. ${ }^{120}$ Under the Code, the exclusive authority to decide whether to settle a suit resides with the client, not with the attorney. ${ }^{121}$ Furthermore, a lawyer must advise a client of settlement opportunities free of the lawyer's self-interests. ${ }^{122}$ Consequently, an attorney must prevent fee-related considerations from affecting his assessment of settlement opportunities if the client is to be provided with disinterested and ethical legal representation. An attorney's entitlement to statutory fees for successfully enforcing congressionally favored rights does not diminish his duty to provide disinterested counsel. A plaintiff's lawyer advising a client against settling a suit solely because the defendant conditions a settlement offer on a waiver of statutorily authorized attorneys' fees thus appears to engage in unethical conduct under the Code. ${ }^{28}$

The Code, however, fails to shield counsel from pressures-such as conditional settlement offers-that could impair disinterested representation. For instance, DR 2-108(B) requires an attorney to decline from entering into "an agreement that restricts his right to practice law."124 Thus, plaintiff's counsel, as a condition of settlement, cannot agree to refrain from representing other plaintiffs in future actions similar to the one being settled. ${ }^{125}$ The Code seeks to bar such agreements because they would induce a conflict between plaintiff's counsel's interests in his own practice and the client's interest in an adequate settlement. ${ }^{126}$ Yet, the Code does not bar opposing counsel from making such settlement offers; it merely bars plaintiff's counsel from agreeing to them. ${ }^{127}$ To address adequately practices the bar may otherwise seek to

120 "In the federal district courts, more than 90 percent of all civil cases . . . are terminated short of trial." Kaufman, Judicial Reform in the Next Century, 29 STAN. L. REV. 1, 1 (1976) (footnote omitted). For official statistics supporting this assertion, see ADMINISTRATIVE OFFICE OF THE UNITED STATES COURTS, ANNUAL REPORT OF THE DIRECTOR 254-57 (1980). For a discussion of factors which may lead parties to settle a suit rather than proceed with litigation, see Note, An Analysis of Settlement, 22 STAN. L. REV. 67 (1969).

121 "[I]t is for the client to decide whether he will accept a settlement offer . . ." MODEL CODE OF PROFESSIONAL RESPONSIBILITY EC 7-7 (1981). See also supra note 109 and accompanying text.

122 See id. EC 5-2 to 5-13.

128 But see infra text accompanying notes 161-63.

124 "In connection with the settlement of a controversy or suit, a lawyer shall not enter into an agreement that restricts his right to practice law." MODEL CODE OF PROFESSIONAL RESPONSIBILITY DR 2-108(B) (1981).

${ }_{125}$ Cr. ABA Comm. on Professional Ethics, Informal Op. 1039 (1968) (a lawyer cannot ethically sign an agreement that settles a client's litigation when the settlement contains a covenant that the lawyer will not represent other plaintiffs against the defendant).

${ }^{128}$ See New York City Bar Ass'n Comm. on Professional and Judicial Ethics, Formal Op. $80-94$ (1981), reprinted in 36 REC. A.B. CITY N.Y., supra note 15, at 507.

127 The Code approaches this type of conflict of interest problem by providing a lawyer with an aid to resisting objectionable conduct rather than prohibiting the conduct itself. $C f$. Rhode, 
proscribe, the Code needs to incorporate provisions focusing on defense counsel's conduct.

\section{B. The New York City Bar Association's Condemnation of Conditional Settlement Offers}

Only one bar ethics committee has taken steps to shield counsel from the "severe dilemma"128 posed by conditional settlement offers. In September, 1981, the Committee on Professional and Judicial Ethics of the New York City Bar Association ("Ethics Committee") issued an opinion deeming it to be unethical for defendant's counsel to offer to settle civil rights litigation in return for waiver of statutorily authorized attorneys' fees. ${ }^{129}$ The Ethics Committee observed that defendant's counsel, in conditioning settlement on the waiver of the statutory fee, "make[s] a demand for a benefit which the plaintiff's lawyer cannot resist as a matter of ethics and which the plaintiff will not resist due to lack of interest." ${ }^{\text {1s0 }}$ The Ethics Committee deemed unethical defendant's counsel's exploitation of this situation in civil rights and civil liberties cases. ${ }^{131}$

The Ethics Committee's condemnation of conditional settlement offers rested on a syllogistic analysis: 1) conditional settlement offers by defendants' counsel "could seriously undermine" the effectiveness of private efforts at enforcing the federal civil rights statutes; ${ }^{\mathbf{1 3 2}} 2$ ) counsel have an ethical duty not to undermine the enforcement of these statutes; $^{\mathbf{1 3 s}}$ therefore, 3 ) defendants' counsel have an ethical duty to refrain from conditioning settlement offers on waiver of statutorily authorized attorneys' fees.

The Ethics Committee relied on case law and the legislative history of the Fees Act as support for its first conclusion. ${ }^{134}$ The cited authority stated that the effective enforcement of the federal civil rights laws depends heavily upon the litigation efforts of private citizens;, ${ }^{\text {19s }}$ that scarce financial resources prevent a majority of the victims of civil

supra note 99, at 709 (footnote omitted): "[Ethical] codes can help lawyers resist overreaching by third parties. An attorney reluctant to invoke only his own moral intuitions in challenging a client's or supervising lawyer's directives might find that code provisions afford more politic means of registering objections."

128 New York City Bar Ass'n Comm. on Professional and Judicial Ethics, Formal Op. 80-94 (1981), reprinted in 36 REC. A.B. CITY N.Y., supra note 15, at 508.

150 See id., reprinted in 36 REC. A.B. CITY N.Y., supra note 15, at 507.

${ }^{180}$ Id., reprinted in 36 REC. A.B. CITY N.Y., supra note 15, at 508.

181 See id.

122 Id., reprinted in 36 REC. A.B. CITY N.Y., supra note 15, at 509.

123 Id., reprinted in 36 REC. A.B. CITY N.Y., supra note 15, at 509-10.

124. See id., reprinted in 36 REC. A.B. CITY N.Y., supra note 15, at 508-09.

12s See supra text accompanying notes 46-48. 
rights violations from securing the requisite legal counsel to initiate litigation; ${ }^{138}$ and that statutorily authorized attorneys' fees thus enable these victims to bring their cases to the courts. ${ }^{137}$ The Ethics Committee implicitly assumed that if plaintiffs' lawyers routinely were to waive their claim to fees ${ }^{188}$ as a condition of obtaining favorable settlements for their clients, the public interest bar would again refuse to represent potential victims. ${ }^{130}$ Such an outcome, the Ethics Committee concluded, would undermine the congressionally enacted scheme of private enforcement of the civil rights laws.

The Ethics Committee strained to find support in the Code for its conclusion that defendants' counsel had an ethical duty not to undermine federal civil rights statutes by offering conditioned settlements. It first cited DR 1-102(A)(5) which mandates that "[a] lawyer shall not . . . [e]ngage in conduct that is prejudicial to the administration of justice."140 The Ethics Committee's reliance on this rule may have been appropriate if attorneys owed a greater duty to the public interest than to their clients. ${ }^{141}$ An attorney's professional duty under the Code, however, is primarily to the client. ${ }^{142}$ By offering a conditioned settlement, a defendant's counsel merely seeks to further his client's interests within the bounds of the law; defendant's counsel does not engage in conduct prejudicial to the administration of justice. In fact, a conditioned settlement in an individual case arguably promotes the administration of justice if the relief offered by the defendant to the plaintiff terminates a violation of a civil rights statute. The conditioned settlement provides the plaintiff with the desired relief, and does so more efficiently than would proceeding to trial.

The Ethics Committee also relied on the Code's ethical considera-

286 See supra text accompanying notes $49 \& 55$.

237 See supra note 58 and accompanying text.

128 The claim to statutory fees, however, may belong to the client rather than to the attorney. See infra note 151 and accompanying text. But see infra text accompanying notes 153-54.

120 Prior to the enactment of the Fees Act many private lawyers had been "refusing to take certain types of civil rights cases because the civil rights bar, already short of resources, could not afford to do so." H.R. REP. NO. 1558, supra note 8, at 3.

${ }^{140}$ MODEL CODE OF PROFESSIONAL RESPONSIBILITY DR 1-102(A)(5) (1981).

142 A lawyer would then ethically be bound to place the interests underlying the Fees Act above the interests of the client. Because conditional settlement offers undermine the continued enforcement of the civil rights statutes, see supra text accompanying notes 60-64, defendant's counsel would ethically be proscribed from making such offers. But see Developments-Conflicts, supra note 98, at 1459-60 (footnote omitted) ("[T]here would be great danger in requiring individual attorneys to override the wishes of their clients in accordance with their personal perceptions of legislative intent and the public interest, because those concepts are too nebulous to provide a standard for judging a lawyer's professional conduct.").

14: See supra text accompanying notes 104-107; cf. Daley \& Karmel, Attorneys' Responsibilities: Adversaries at the Bar of the SEC, 24 EMORY L.J. 747, 772 (1975) ("The notion that a private attorney owes a duty to the public which overrides his duty to his client is alien to the traditions and ethical standards of the legal profession." (footnote omitted)). 
tions. The Committee first condemned conditional settlement offers as contrary to a lawyer's duty under EC 2-25 "to support efforts to make counsel available to those unable to afford it."143 It then sought to buttress its conclusions by citing EC 7-14 which discourages government counsel ${ }^{144}$ from using the government's economic power "to bring about unjust settlements."145 Yet, reliance on the notion of "unjust settlement" to prove that conditional settlement offers are ethically wrong begs the question. Only if conditional settlement offers were deemed unjust would EC 7-14 urge government counsel to refrain from making such offers. Canon $5,{ }^{146}$ however, urges plaintiffs' attorneys to exercise their own independent judgment in determining whether the defendant's settlement offer affords satisfactory relief to the plaintiff. A conditional settlement offer would not constitute an unjust settlement if it afforded satisfactory relief to the plaintiff. Consequently, as long as the defendant affords relief satisfactory to the plaintiff, EC 7-14 does not admonish government counsel to refrain from making conditional settlement offers.

In summary, the Ethics Committee recognized that the future vindication of civil liberties under the Constitution and federal statutes depends on the actual awarding of statutory attorneys' fees to counsel of prevailing plaintiffs in civil rights cases. The Committee sought to shield plaintiffs' lawyers from the conflict of interests induced by conditional settlement offers by precluding "defendant[s'] lawyer[s] from holding the settlement[s] of the merits hostage to . . . waiver[s] of the statutory fee."147 The Committee's attempt to derive support from the Gode for its condemnation of this practice, however, does not bear up under scrutiny. The Code, oriented toward fee paying clients and the vindication of paying clients' rights without regard to the public inter-

168 New York City Bar Ass'n Comm. on Professional and Judicial Ethics, Formal Op. 80-94 1981, reprinted in 36 REC. A.B. CITY N.Y., supra note 15, at 510. EC 2-25 provides in part that "[e]very lawyer should support all proper efforts to meet this need for legal services lof those unable to pay reasonable fees]." MODEL CODE OF PROFESSIONAL RESPONSIBILITY EC 2-25 (1981).

${ }^{144}$ Most defendants in civil rights suits are government officials or entities. See New York City Bar Ass'n Comm. on Professional and Judicial Ethics, Formal Op. 80-94 (1981), reprinted in 36 REC. A.B. CrTY N.Y., supra note 15, at 507; H.R. REP. No. 1558, supra note 8, at 7. For instance, section 1983 of 42 U.S.C. provides relief only against persons acting under color of state law. See Monell v. Department of Social Servs., 436 U.S. 658 (1978); Monroe v. Pape, 365 U.S. 167 (1961).

i4s MODEl Code of Professional Responsibility EC 7-14 (1981).

116 "A Lawyer Should Exercise Independent Professional Judgment on Behalf of a Client." Id. Canon 5. One reason attorneys are ordinarily prohibited from acquiring a financial interest in the outcome of the litigation they are conducting for their client, see id. DR 5-103(A), is the "possibility of an adverse effect" upon a lawyer's exercise of free judgment on behalf of his client. Id. EC 5-7.

117 New York City Bar Ass'n Comm. on Professional and Judicial Ethics, Formal Op. 80-94 (1981), reprinted in 36 REC. A.B. CITY N.Y., supra note 15, at 511. 
est, ${ }^{148}$ provides little support for the view that attorneys have an ethical duty to refrain from conditioning settlement offers on waivers of statutory fees. ${ }^{148}$

\section{Conditional Settlement Offers and the Judiciary's Role in Furthering the Goals of THe FeEs ACt}

If a defendant insists on a waiver of statutory fees as a condition of settlement, if the defendant's settlement offer otherwise satisfied the plaintiff, and if neither the Code nor the trial court shields the plaintiff's counsel from the defendant's demand during settlement negotiations, ethical counsel apparently has no choice but to yield to the fee waiver on behalf of the client's best interests. As in Chattanooga Branch of the NAACP v. City of Chattanooga, ${ }^{180}$ counsel's only judicial means to challenge the propriety of a defendant's conduct may be a postjudgment motion setting aside the fee waiver.

Yet, courts routinely characterize the entitlement to statutory fees as belonging to the prevailing party, not to the lawyer. ${ }^{151}$ If the right to the statutory fee belongs to the client rather than the lawyer, then the lawyer cannot claim that a defendant's conditional settlement offer placed him in a conflict of interest ${ }^{162}$ nor may he proceed with a postjudgment motion for fees without the client's consent. One federal court of appeals, however, has clearly held that the right to fees is the lawyer's, not the client's. ${ }^{153}$ Moreover, almost every court that has considered the issue of entitlement to fees has recognized that a motion for fees in a civil rights case, "although made in the name of the plaintiff,

148 See Developments-Conflicts, supra note 98, at 1446.

199 The extensive conflict-of-interests provisions of the American Bar Association's Model Rules of Professional Conduct ("Model Rules"), the proposed successor to the Code, also fail to shield counsel from conditional settlement offers. See MODEL RULES OF PROFESSIONAL CONDUCT Rules 1.7 to 1.13 (Final Draft, August, 1982). Furthermore, the Model Rules preserve the notion that attorneys serve the public interest when they zealously represent the private interests of their clients. See, e.g., id. Preamble ("A lawyer's responsibilities as a representative of clients, an officer of the legal system and a public citizen are usually harmonious.").

160 No. 79-2111 (D. Tenn. Dec. 2, 1981), appeal dismissed, Nos. 82-5016/13 (6th Cir. Apr. 29,1982 ) (discussed supra notes $71-75$ and accompanying text).

181 See, e.g., Allen v. Burke, 690 F.2d 376, 379 (4th Cir. 1982) ("[prevailing party is] entitled to an award of attorney fees"); White v. New Hampshire Dep't of Empl. Sec., 629 F.2d 697, 705 (1st Cir. 1980) ("plaintiff's fees claim"), rev'd on other grounds, 455 U.S. 445 (1982).

182 If the right to the statutory fee is the client's, then strictly speaking there is no attorney interest in conflict with the client's: the client waives her or his right to file a motion for fees in return for a settlement favorable to herself or himself. The Committee, however, stated that "the distinction is at best theoretical because in the typical case only the lawyer has a practical interet [sic] in the statutory fec." New York Bar Ass'n Comm. on Professional and Judicial Ethics, Formal Op. 80-94 (1981), reprinted in 36 REC. A.B. CITY N.Y. supra note 15, at 513 n.5 (citation omitted).

183 James v. Home Constr. Co., 689 F.2d 1357 (11th Cir. 1982); see supra note 67. 
is really one by the attorney."154 Especially where the plaintiff is under no obligation to pay counsel or the recovery yields no funds to pay counsel, the real party in interest in a motion for fees is the attorney. Hence, the uniform practice of the federal courts, including the Supreme Court, is to direct payment of statutory attorneys' fees to the lawyers themselves. ${ }^{158}$ The fees awards are made directly to the lawyer "to ensure against a windfall to the litigants."158

The potential for fee recovery is an important factor a lawyer considers in deciding whether to represent a client otherwise unable to pay for legal counsel. ${ }^{167}$ It encourages a lawyer to expend his limited resources in litigation aimed at enforcing civil rights statutes. ${ }^{168}$ Furthermore, the funds derived from a fees award may secure adequate representation for the lawyer's future clients seeking enforcement of their civil rights. ${ }^{158}$ Fee recovery thus enhances a lawyer's capabilities to assist in enforcing congressionally secured individual rights. ${ }^{160}$ Conversely, denial of fees restricts the lawyer's ability to represent other clients subsequently seeking judicial relief. In routinely yielding to defendants' conditional settlement offers, a lawyer effectively agrees not to represent other persons financing their suits by means of the Fees Act or other fee shifting statutes.

In some instances, then, a settlement agreement in which the lawyer waives the claim to fees may be analogous to a covenant restricting a lawyer's right to practice: in both the lawyer agrees not to represent a certain class of clients. Although the express terms of the conditional settlement agreement may merely require counsel to waive any entitlement to statutory fees rather than agree not to represent other persons,

${ }^{166}$ Regalado v. Johnson, 79 F.R.D. 447, 451 (N.D. Ill. 1978); see, e.g., Lipscomb v. Wise, 643 F.2d 319 (5th Cir. 1981); Rodriguez v. Taylor, 569 F.2d 1231, 1245 (3rd Cir. 1977), cert. denied, 436 U.S. 913 (1978); Hairston v. R \& R Apartments, 510 F.2d 1090, 1092-93 (7th Gir. 1975); Brandenburger v. Thompson, 494 F.2d 885, 889 (9th Cir. 1974).

${ }_{185}$ See, e.g., Maher v. Gagne, 448 U.S. 122, 126 (1980) (fees awarded to "respondent's counsel"); New York Gaslight Club, Inc. v. Carey, 447 U.S. 54, 70-71 n.9 (1980) (fees awards to "public interest groups" are appropriate); Hutto v. Finney, 437 U.S. 678, 693 (1978) (appellate fees were ordered to be paid "to counsel for the prevailing parties").

158 Brandenburger v. Thompson, 494 F.2d 885, 889 (9th Cir. 1974); accord Miller v. Amusement Enterprises, Inc., 426 F.2d 534, 539 (5th Cir. 1970) ("the fees allowed are to reimburse and compensate for legal services rendered and will not go to the litigants"); see also Rodriguez v. Taylor, 569 F.2d 1231, 1245 (3d Cir. 1977); Hairston v. R \& R Apartments, 510 F.2d 1090, 1093 (7th Cir. 1975).

$16 z$ "Public interest law firms" seeking tax exempt status under $\S 501(c)(3)$ of the Internal Revenue Code of 1954, 26 U.S.C. \$ 501(c)(3) (1976), may not, however, use "the likelihood or probability of a fee award as a consideration in its selection of cases." Rev. Proc. 75-13, \& 3, 1975 1 C.B. 662; see Rev. Rul. 76-5, 1976-1 C.B. 146; Rev. Rul. 75-76, 1975-1 C.B. 154.

${ }^{168}$ See Dennis v. Chang, 611 F.2d 1302, 1306 (9th Cir. 1980).

188 See Note, Awards of Attorney's Fees to Legal Aid Offices, 87 HARV. L. REv. 411, 414 (1973).

1eo See Rodriguez v. Taylor, 569 F.2d 1231, 1245 (3d Cir. 1977). 
the effect of those terms may be the same: successfully representing the client's interests in the settlement negotiations at issue necessarily entails yielding to a settlement demand that curbs the lawyer's ability to represent other clients. Both DR $1-108(B)^{\mathbf{1 6 1}}$ and its equivalent under the proposed successor to the Code, Model Rule 5.5(b), ${ }^{162}$ however, prohibit "a lawyer from agreeing not to represent other persons in connection with settling a claim on behalf of a client."16s Where agreeing to a conditional settlement offer effectively precludes the lawyer from subsequently representing clients dependent on a fee shifting statute, yielding to a defendant's demand-even in the client's best interest-may be contrary to the rules of ethics.

Furthermore, denial of statutory fees to plaintiffs' lawyers through conditional settlement offers undermines the enforcement scheme designed by Congress. The routine bargaining away of statutory fees-whether by plaintiffs who have no financial interest in them or by their ethical but coerced counsel-diminishes lawyers' expectations of statutory fees in civil rights cases. Lawyers who undertake civil rights cases will do so at their peril. The pool of lawyers willing to represent plaintiffs in civil rights cases may shrink, forcing victims of civil rights violations once again to rely on the "charitable instincts of a few generous attorneys" for their legal representation-contrary to Congress's purpose in enacting the Fees Act. ${ }^{164}$ Conditional settlement offers deter lawyers from representing future plaintiffs who must rely on the Fees Act to finance their legal representation. This inevitable chilling effect on the plaintiffs' civil rights bar caused by conditional settlement offers frustrates the basic policies of the Fees Act.

Conditional settlements where plaintiffs' counsel voluntarily offer or agree to waive their claims to fees, however, pose no threat to the Fees Act. A lawyer who voluntarily waives fees in one settlement agreement has no basis to fear that a future defendant will coerce waiver of attorneys' fees. Further, if barred by the rules of ethics, ${ }^{165}$ an ethical lawyer presumably would not waive attorney's fees if to do so would effectively restrict his ability to represent other clients. Hence, voluntary fee waivers do not deter or disable a lawyer from represent124).

101 MODEL CODE OF PROFESSIONAL RESPONSIBILITY DR 2-108(B) (1981) (quoted supra note

162 "A lawyer shall not participate in offering or making ... an agreement in which a restriction on the lawyer's right to practice is part of the settlement of a controversy between private parties." MODEL RULES OF PROFESSIONAL CONDUCT Rule 5.5(b) (Final Draft, Aug., 1982).

${ }^{163}$ Id. comment.

104 See Northcross v. Board of Educ., 611 F.2d 624, 638 (6th Cir. 1979), cert. denied, 447 U.S. 911 (1980).

103 See supra text following note 163. 
ing future clients.

On the other hand, conditional settlements reached by coercing plaintiffs' counsel into waiving their fees do undermine the congressional policy underlying the Fees Act by disabling or deterring lawyers from representing future clients. Courts should protect the Fees Act and further its goals by shielding plaintiffs' lawyers from the coercion inherent in defendants' repeated insistence on conditioning settlement on waiver of fees. Courts should not adopt a rigid Prandini rule because it may prevent lawyers from voluntarily waiving fees or preclude defendants from obtaining information on which to determine their total liability. ${ }^{18 B}$ Nor should courts adopt an approach that requires them to second guess a plaintiff's counsel's determination that waiving the claim to fees would effectively preclude her or him from representing certain clients. The court need shield a plaintiff's lawyer from simultaneous negotiations and conditional settlement offers only upon the lawyer's own request. Absent a request by a plaintiff's lawyer, the court may assume that the ongoing settlement negotiations pose no threat to the Fees Act.

A rule that bars simultaneous negotiations only upon a plaintiff's lawyer's request would halt the continued undermining of the Fees Act. Safe from coercive conditional settlement offers, lawyers could prejudge the likelihood of receiving reimbursement: statutory fees would be awarded as a matter of course whenever the lawyer successfully represented the plaintiff in a civil rights suit. The ensurance of a fees award furthers the policies behind the Act by "encourag[ing] litigation of the types of actions Congress sought to stimulate."167

Shielding plaintiffs' lawyers from the coercive pressures of simultaneous negotiations may result in fewer settlement agreements. A defendant, rather than settling a plaintiff's claim, may seek to defeat it in order to avoid liability for the fees award. As one court observed, "it is doubtful that Congress envisioned that [the Fees Act] would become the catalyst for litigating a claim which otherwise would be settled."168

Yet, Congress primarily sought to provide private citizens with the financial means to secure legal counsel in civil right suits. ${ }^{169}$ The Fees Act accomplishes Congress's goal when a lawyer represents a plaintiff in an effort to obtain judicial enforcement of rights under the federal civil rights laws. The Fees Act has and must continue to be a catalyst for litigating civil rights claims that otherwise would never have been

\footnotetext{
166 See supra note 90.

107 Vindication of Civil Rights, supra note 1, at 352.

16 Skoda v. Fontani, 519 F. Supp. 309,310 (N.D. Ill. 1981)

100 See supra text following note 55 .
} 
filed in court due only to the high costs of legal counsel. The goal of settling rather than litigating meritorious claims must not subvert Congress's intent in enacting the Fees Act. 
